\title{
A Delve Into The Deployment Of eCommerce And Higher Educational Learning
}

\author{
Wilhelmina Djoleto, CulRitzWil Co. USA. \& Youngstown State University, USA
}

\begin{abstract}
Higher Educational Institutions (HEIs) and organisations have made significant investments in eCommerceleBusiness in efforts to keep up with heightened technology penetration in organisational and institutional fabrics. These efforts have been incorporated in their strategic mission partly, to bolster their reputation. HEIs reputation depends much on their delivery of education to their clientele (students); thus, their endeavours to invest in eCommerce solutions. In reconnoitring the impact of eCommerceleBusiness at HEIs, higher level administrators at randomly selected cluster sample of historically black colleges and universities in America were surveyed. A mixed method analysis showed positive impact between eCommerce/eBusiness and student learning, student satisfaction, student conflict resolution.
\end{abstract}

Keywords: eBusiness; eCommerce; eEnrolment; eLearning; eStudent-Conflict-Resolution

\section{INTRODUCTION}

ust as Information Technology (IT) has come to permeate just about every bit of institutional fabrics, eCommerce/eBusiness, a critical component of IT, in recent times has become the quintessence of day to day institutional operations at Higher Educational Institutions (HEIs). And the deployment of information technology and eCommerce has led to increased flexibility in business operations, including course delivery, in terms of eLearning (Chnapko, 2002, Djoleto, 2008a, Djoleto, 2008b), as well as distant education and Course Management Systems (CMS), eAdmissions and eRegistration. This rapid improvement in information technology brought about astronomical growth in CMS needed for effective distance education, a component of eCommerce. The heightened need for eCommerce/eBusiness solutions translates to the high demand for software such software models (consolidated/integrated) developers for HEIs (Djoleto, 2009; Gil-Garcia \& Pardo, 2006; Olsen, 2000 \& 2002).

With this wave, higher educational institutions and organisations that have not yet embraced eBusiness struggle to compete in the competitive global market. Consequently, many HEIs have invested significantly and have strategically embarked on online course offerings and eCommerce-based academic activities to boost student enrolment and improve student academic performance while providing quality education and placing them strategically above their competitors (Djoleto-Okunbor, 2009; Armstrong, 2002). Green embarks and reports on his ongoing survey of IT implementations at HEIs focusing generally on acquisitions of computer hardware and software and the development of information technology and telecommunication service unit of the organisation. Examples of these areas include offices, classrooms, and residence halls, campus dial-up capacities for faculty, staff and students (Green, 2000). According to Green's (2006) survey, 51.2\% of college classrooms have wireless networks, a leap from $42.7 \%$ in 2005 and $31.1 \%$ in 2004 . More than $68.8 \%$ of campuses that participated in Green's annual survey have a strategic plan to deploy wireless by fall 2006 (Green, 2006). This infrastructure provides enhanced environment for the adoption of eBusiness (Green, 2000).

While eCommerce solutions help promote customer-company relationships in industry settings that translate into customer satisfaction, in higher education institutions, customers are students and therefore, students' 
satisfaction measures vitality and viability of the academic programs at the institution (Armstrong, 2002; (Devaraj, Fan \& Kohli, 2002); Djoleto, 2008). Students' satisfaction may depend on their commitment to the institution vis-àvis their desire to attend that institution. The electronic chat and instant messaging are becoming ubiquitous applications in higher education institutions. These two technologies, along with electronic mail service and video conferencing form the bedrock of the eConferencing solution at institutions and are used on a daily basis for conflict resolutions. (Warger, 2003). (Djoleto-Okunbor, 2009; Gunasekaran, McGaughey \& McNeil, 2004; Kalakota \& Robinson, 2000; Ralston, Burke, Nakayama \& Tolani, 2000).

The fluidity of data and information calls for vital attention to ensuring that these organisations and institutions ensure consistency, integrity, effeciency and effectiveness in the application of eBusiness solutions (Djoleto-Okunbor, 2008a, Djoleto-Okunbor, 2008b; Djoleto-Okunbor, 2008c; Kleiner \& Maury, 2002; Kvavik, 2002; Robertson and Sarathy, 2003; Schneider, 2003).

This study reconnoitred a sample of 715 higher echelon administrators deemed erudite about their institutions' eCommerce solutions and ranking from Presidents/Chancellors to Directors and Deans from a random cluster sample of 55 HBCUs. Such institutions, as designated by U.S. Congress, were originally designed for underrepresented blacks who were denied education at Traditionally White Institutions (TWIs). Figure 1 depicts the relation between eCommerce and higher educational learning components.

N.B.:- Tables and figures are available from author upon request.

\section{BIVARIATE ANALYSIS}

From the table, the NoECS correlates positively with NSER ( $\mathrm{R}=0.264, \mathrm{P}=0.0001)$, CSEC $(\mathrm{R}=0.320$, $\mathrm{P}=0.001)$. The variable InECS correlates positively with NSEAA $(\mathrm{R}=0.224, \mathrm{P}=0.013)$, NOC $(\mathrm{R}=0.301, \mathrm{P}=0.001)$, NSOC $(\mathrm{R}=0.261, \mathrm{P}=0.004)$, NSER $(\mathrm{R}=0.314, \mathrm{P}-0.0001)$, CSEC $(0.226, \mathrm{P}=0.026)$. The variable IaECS correlates positively with NSEAA $(\mathrm{R}=0.185, \mathrm{P}=0.030)$, NOC $(\mathrm{R}=0.172, \mathrm{P}=0.040)$, NSOC $(\mathrm{R}=0.172, \mathrm{P}=0.038)$, NSER $(\mathrm{R}=0.332, \mathrm{P}=0.0001), \mathrm{CSEC}(\mathrm{R}=0.414, \mathrm{P}=0.0001)$.

Equally noticeable from the table 1 is that the dependent variable NaECS did not correlate significantly with any of the independent variables. Clearly, the length of time an eCommerce solution is implemented at an institution is not affected by any of the exploratory factors. It seems that once an eCommerce solution is adopted, it is generally updated for improved functionality and effectiveness and such replacement is seamless to affect the opinion of the respondents. The content analysis of the open ended questions in the survey instrument also supports this exegesis.

\section{CONTENT ANALYSIS}

Out of the 53 institutions from 22 states that participated, 24 institutions constituting $45.28 \%$ (47 Administrators overall) are either at initial stages of eCommerce implementation or had not acquired or invested adequately in eCommerce. These institutions are yet to experience full impact of eCommerce solutions in their daily administrative operations. Despite this, the content analysis of the responses to the open-ended questions result complements the quantitative analysis.

Also, 34 institutions approximately $64.15 \%$ (80 Administrators overall) of the participating institutions indicated higher investment in eCommerce and increased job productivity of administrators due to eCommerce solutions. There was an indication that eCommerce solutions bolster satisfaction among administrators, faculty and students

\section{CONCLUSION}

These findings have provided direct relationships between variables pertinent to yielding positive impact of eCommerce solutions at institutions. Additionally, over half of the administrators from the study perceive that eCommerce solutions impact student enrolment positively. Students' satisfaction is sustained by adequate 
eCommerce solutions. eCommerce solutions facilitate and promote faster and effective conflict resolution among students. Furthermore, over half of the administrators from the study perceive that eCommerce solutions impact student enrolment positively.

\section{AUTHOR INFORMATION}

Dr. Wilhelmina Djoleto is an Assistant Professor at Youngstown State University. She is also the Founder, President and CEO of the CulRitzWil Co., a Management and Computer Information Systems Consultancy and a Culinary Services Company. She holds a BSc. degree in Computer Science, an M.S. in Applied Computer Science and a Ph.D. degree in Organizational Leadership from the University of Maryland Eastern Shore (UMES). Also, UMES, Dr. Djoleto held positions of Database Manager and Administrator and Lecturer. She teaches both graduate and undergraduate students. Dr. Djoleto has authored/co-authored several research publications spanning symplectic integration for power systems and the impact of eBusiness on institutions and organisations and serves as a reviewer for numerous journals. E-mail: wdjoleto@ysu.edu

\section{REFERENCES}

1. Armstrong, C.P., \& Sambamurthy, V. (1999). Information technology assimilation in firms: the influence of senior leadership and IT infrastructures. Information Systems Research, 10(4), 304-327.

2. Djoleto, W. (2008a). ecommerce solutions and eleadership: Impact analyses on historically black colleges and universities and their organizational leadership, WSEAS Applied Computer Science, Venice Italy.

3. Djoleto, W. (2008b). Effect of ebusiness solutions and eleadership: Impact analyses on higher educational institutions and their organizational leadership, International Journal of Education and Information Technologies. 3(2), 202-211.

4. Djoleto, W., (2009). E-commerce solutions: An impact analysis on historically black colleges and universities, Proceedings of the WDSI $38^{\text {th }}$ Annual Meeting, Kauai, Hawaii.

5. Djoleto-Okunbor, W. (2008a). E-business solutions at historically black colleges and universities: Impact analyses, Global Digital Business Review 3(1), 7-12.

6. Djoleto-Okunbor, W. (2008b). Impact analysis of e-commerce applications at historically black colleges and universities, MTMI Journal and Review of Business and Technology Research, 1(1), 1-6.

7. Djoleto-Okunbor, W. (2008c). The effect of e-business/e-commerce applications at higher educational institutions, Journal of Decision Science and Information Technology, 1(1).

8. Djoleto-Okunbor, W. (2009). E-commerce solutions at historically black colleges and universities: An Impact Analysis, International Journal of Effective Management, 6(1), 19-28.

9. Gil-Garcia, J.R., (2006). Enacting websites: A mixed method study exploring e-government success in multi-organizational settings. IEEE Proceedings of the $39^{\text {th }}$ Hawaii International Conference on System Sciences.

10. Kalakota, R., \& Rohinson, M. (2000). Electronic commerce. In Encyclopedia of Computer Science (4 ${ }^{\text {th }}$ $E d$.), 628-634. London: Nature Publishing Group.

11. Kvavik, R. B. (2002). E-business in higher education. In R. N. Katz (Ed) \& Associates. Web portals and higher education: Technologies to make IT personal. Jossey-Bass Inc. Indianapolis, IN.

12. Olsen, F. (2000), E-commerce may help colleges cut costs and paperwork. Chronicle of Higher Education, 46(33), A45-46.

13. Ralston, G., Burke, K., Nakayama, D. \& Tolani, A. (2000). Electronic mail. In Encyclopedia of Computer Science ( $4^{\text {th }}$ ed. pp. 637-642). London: Nature Publishing Group.

14. Sarathy, R. \& Robertson, C.J. (2003), Strategic and ethical considerations in managing digital privacy. Journal of Business Ethics, 46(2). 111-126

15. Schneider, G. P. (2003). Electronic commerce ( $4^{\text {th }}$ ed). Boston, MA: Thomson Learning Inc.

16. Warger, T. (2003, April). Calling all course management systems. University Business, 64-65. 
NOTES 